\title{
LIFE HISTORY OF DYSODIA SICA \\ (LEPIDOPTERA: THYRIDIDAE) \\ IN PANAMA ${ }^{1}$
}

By Annette Aiello

Smithsonian Tropical Research Institute

P.O. Box 2072, Balboa, Panama

Thyrididae is a widespread tropical and subtropical family of moths, generally thought to be related to the Pyralidae, from which they differ in a number of ways (see Whalley, 1971). Possibly the group is not monophyletic, but so little is known concerning the immature stages, that few conclusions can be reached regarding the relationships among the four subfamilies.

Dysodia (Thyrididae: Pachythyrinae) is a pantropical genus found on all continents except Australia (Whalley, 1971). Aside from scattered foodplant records for several species, little is known about the immature stages of any of the approximately thirty species. The present paper describes the egg, larvae, pupa, and larval behavior of Dysodia sica Druce (Figure 1) reared on Barro Colorado Island (BCI), Panama, during May through August 1977 and 1980. Seven other species of Dysodia are listed for BCI by Forbes (1942).

\section{Adult Behavior}

Adults of Dysodia spp. fly during early evening, and are seen frequently at lights on BCI. At rest, the wings are horizontal to the substrate, with the fore wings almost completely covering the hind wings (Figure 2). This resting posture, triangular in outline, is also common among many pyralid moths. When alert or about to fly, the fore wings are drawn forwards, exposing the hind wings, and bringing the markings of the fore and hind wings into alignment (Figure 3). The two "windows" on each hind wing show just behind the posterior margin of the fore wings. The fore wings are curved longitudinally so as to be somewhat concave above.

\footnotetext{
${ }^{1}$ Manuscript received by the editor December 4, 1980.
} 


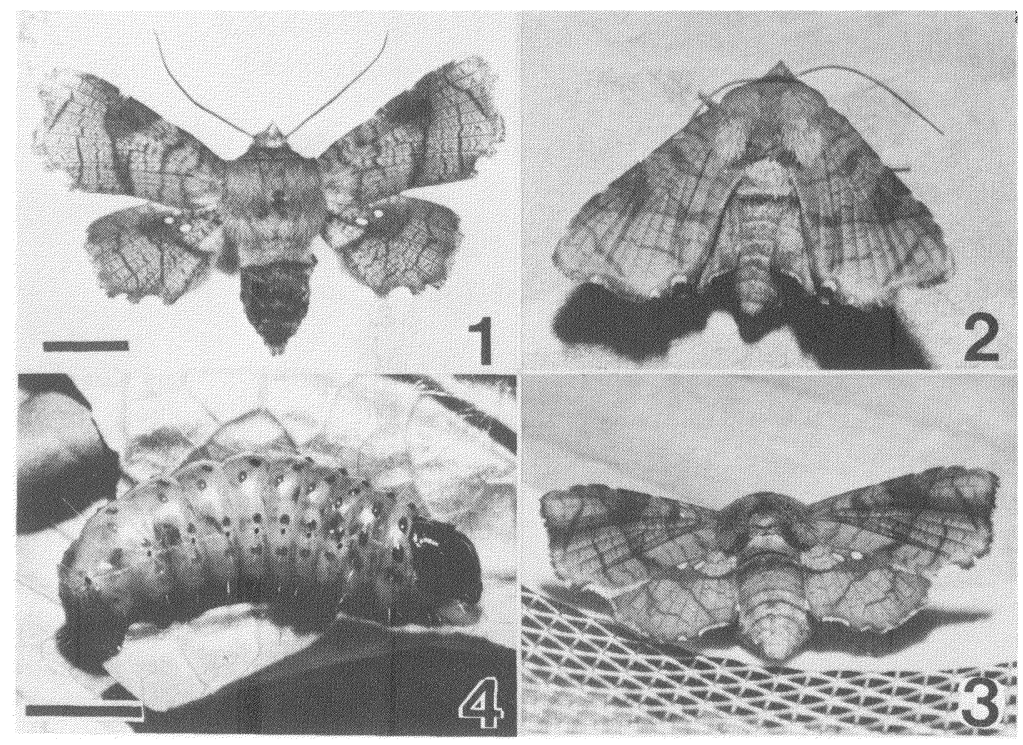

Figures 1-3. 1. Dysodia sica adult female (Lot 80-2). 2. Adult female (Lot 77-17) in triangular resting posture. 3. Same individual in wing-spread resting posture. 4. Same individual as final instar larva shortening for pupation. Scales $=5 \mathrm{~mm}$.

\section{FOODPLANTS}

Foodplant records for Dysodia are few (Table 1), and involve several unrelated plant families.

Dysodia sica on BCI was found on two species of the Piperaceae: Piper marginatum (Figure 5) and Pothomorphe peltata (Figure 6). Both species are abundant weeds in the Laboratory Clearing, and have similar leaf texture, odor, and growth form.

\section{IMMATURE STAGES}

\section{Egg}

Eggs (Figure 10) are deposited upon the upper surface, near the center of larval host plant leaves. Normally only one egg is laid per leaf. However, several leaves on a plant may receive them.

Eggs are yellow-orange, cylindrical, $1.5 \mathrm{~mm}$ tall and $0.9 \mathrm{~mm}$ in diameter. They have a circle of 16-20 papillae around the periphery of the top. Except for a smooth area in the center of the top, 


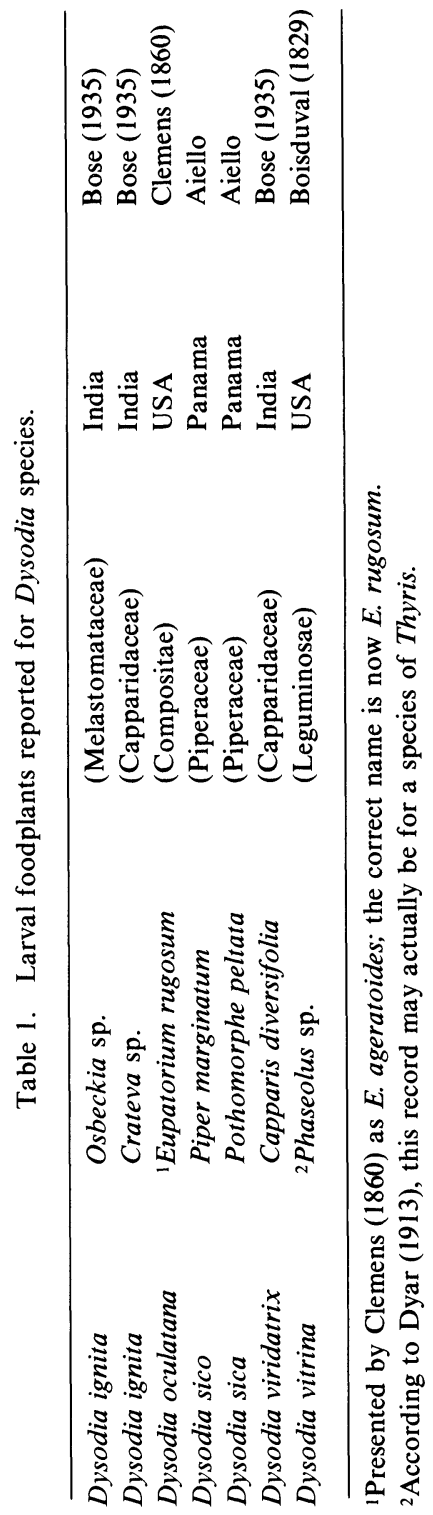


containing the micropyle, the surface is entirely covered with a reticulate pattern of hexagonal cells.

Larvae

Hatching

The first instar larva eats its way through the egg apex 5-6 days after oviposition and consumes additional shell before attacking the leaf.

\section{Behavior}

After hatching, the larva constructs its first shelter by making a cut, about $1 \mathrm{~cm}$ long, perpendicular to the edge of the leaf. As it cuts, it rolls and crimps the cut portion of the leaf and fastens it in place with silk. The result is a conical chamber (Figure 7), closed at the top; open at the bottom. The chamber may be constructed on either the right or left edge of the leaf, and may be rolled over the upper surface or the lower surface of the leaf. Thus, four configurations are possible.

As the larva feeds upon the inner layers of its shelter, it plugs the open end with frass and molted head capsules, probably as a barrier to intruders.

Second and later instars turn and continue the cutting and rolling parallel to the leaf edge, until as much as half the perimeter of the leaf has been rolled (Figure 8).

After consuming most of the rolled portion of the leaf, the larva moves to another leaf. Later larvae construct shelters beginning higher up on the leaf, often within a few centimeters of the attachment of blade and petiole. As a result, almost the entire leaf blade is rolled (Figure 9).

Similar shelters have been described for Dysodia by past workers. Clemens (1860) noted that $D$. oculatana in eastern United States “... feeds... beginning on one side of a leaf to form a cone or cornet, cutting and rolling the separated portion, as it increases in size, sometimes across the entire leaf."

Forbes (1942), speaking of Dysodia spp. on BCI, commented "Larva forming a very messy and foul-smelling nest (whence the generic name)...."

Number and Duration of Instars

There are five larval instars. Instar durations for seven reared individuals are given in Table 2. 

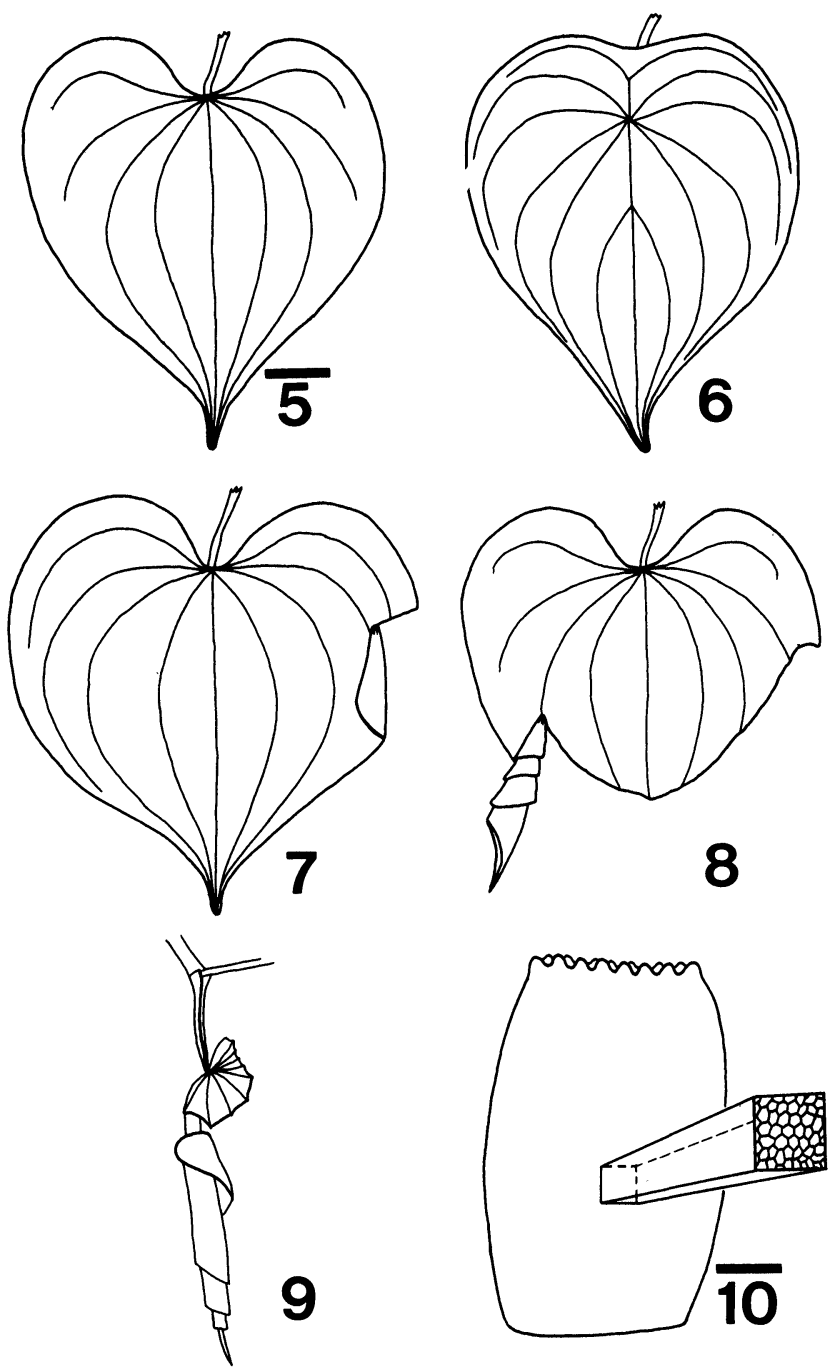

Figures 5-10. 5. Leaf of Piper marginatum. 6. Leaf of Pothomorphe peltata. 7. Leaf roll made by first instar Dysodia sica. 8. Leaf roll made by fourth instar larva. 9. Leaf roll made by final instar larva. Scale $=23 \mathrm{~mm}$. 10. Egg, showing portion of recticulate sculpturing. Scale $=0.25 \mathrm{~mm}$. 
Table 2. Number of days in each instar for the seven individuals in rearing Lot 80-55. $\mathrm{PR}=$ preserved, $\mathrm{s}=$ standard deviation, $\mathrm{N}=$ sample size .

\begin{tabular}{|c|c|c|c|c|c|c|c|c|c|c|c|}
\hline & & & & livid & & & & & & & \\
\hline & 1 & 2 & 3 & 4 & 5 & 6 & 7 & range & mean & $\mathrm{s}$ & $\mathbf{N}$ \\
\hline egg & 5 & 5 & 5 & 5 & 5 & 5 & 5 & 5 & 5 & 0 & 7 \\
\hline instar 1 & 2 & 2 & 3 & 2 & 2 & 2 & 2 & $2-3$ & 2.14 & 0.38 & 7 \\
\hline instar 2 & 4 & 3 & 2 & 4 & 3 & 4 & 2 & $2-4$ & 3.14 & 0.90 & 7 \\
\hline instar 3 & 2 & 2 & 3 & 3 & 3 & 3 & 3 & $2-3$ & 2.71 & 0.49 & 7 \\
\hline instar 4 & 4 & 4 & 3 & 4 & 4 & 3 & 2 & $2-4$ & 3.43 & 0.79 & 7 \\
\hline instar 5 & 9 & 11 & 9 & 9 & 10 & 9 & 9 & $9-11$ & 9.43 & 0.79 & 7 \\
\hline pupa & 70 & PR & 59 & 22 & 61 & 64 & 21 & $21-70$ & 49.50 & 22.01 & 6 \\
\hline total days & 96 & - & 84 & 49 & 88 & 90 & 44 & $44-96$ & 75.17 & 22.60 & 6 \\
\hline $\begin{array}{l}\text { total days } \\
\text { non-diapause } \\
\text { individuals }\end{array}$ & & & & 49 & & & 44 & $44-96$ & 46.50 & 3.54 & 2 \\
\hline total days & & & & & & & & & & & \\
\hline individuals & 96 & & 84 & & 88 & 90 & & $84-96$ & 89.50 & 5.00 & 4 \\
\hline $\operatorname{sex}$ & $\hat{\sigma}$ & 우 & $\hat{\sigma}$ & $\hat{\sigma}$ & ㅇ & $\hat{\sigma}$ & $\hat{\theta}$ & & & & \\
\hline
\end{tabular}

\section{First Instar}

Upon emergence from the egg, the first instar larva has a black head $(0.6 \mathrm{~mm}$ wide) and cervical shield. The prothorax just ventral to the shield is pink. The body is yellow-orange and has black setae and spiracles. After eating and expanding somewhat, the body becomes white and remains so through remaining instars. The arrangement of the head capsule setae is shown in Figure 11.

All body setae are primary and are arranged as in the setal maps (Figure 12). Terminology used is that of Peterson (1962). Meso- and metathorax are identical except for the following differences: the spiracle on segment 8 is larger and is placed higher on the body than are those of the other segments. The $p i$ group consists of one seta on segments $1,7,8$, and 9; and two setae on segments $2-6$.

The crochets on the prolegs of abdominal segments 3-6 are uniserial and biordinal, and are arranged in a complete circle; those on segment 10 form a crescent on the anterior edge of the prolegs.

The suranal plate bears eight setae (Figure 12). 

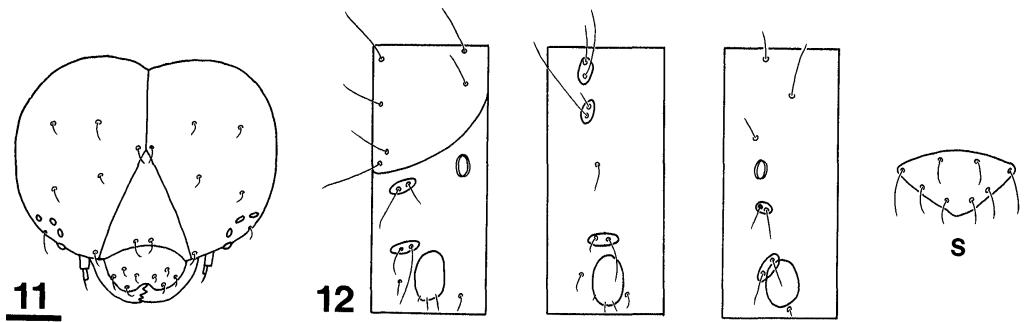

$\mathbf{S}$
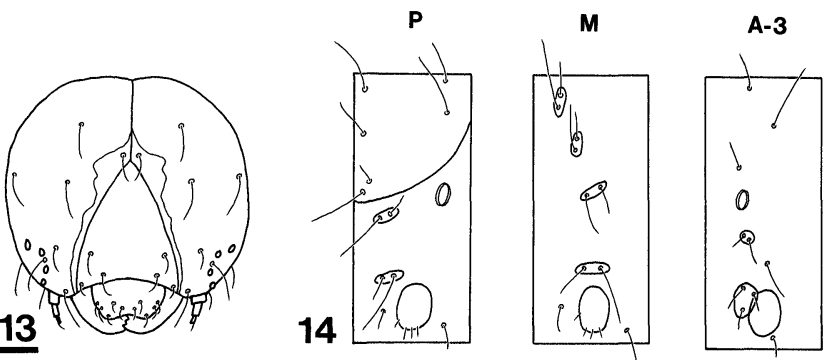

A-9

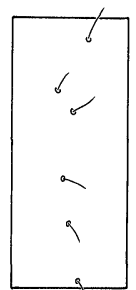

Figures 11-14. 11. Head capsule of first instar. Scale $=0.125 \mathrm{~mm} . \quad$ 12. Setal maps of first instar prothorax (P), meso- and metathorax (M), abdominal segment three (A-3), and first through final instar suranal plate (S). 13. Head capsule of final instar. Scale $=2 \mathrm{~mm}$. 14. Setal maps of final instar prothorax, meso- and metathorax, abdominal segment three, and first through final instar abdominal segment nine (A-9).

\section{Later Instars}

Second through final instar larvae have black head and cervical shield. The body is white with black setae and spiracles.

The arrangement of the head capsule setae is shown in Figure 13. Average head capsule widths for the five instars were $0.6 \mathrm{~mm}, 0.9$ $\mathrm{mm}, 1.4 \mathrm{~mm}, 2.1 \mathrm{~mm}$, and $3.2 \mathrm{~mm}$ for the seven individuals reared from eggs (Lot 80-55).

The arrangement of the body setae in second through final instar larvae (Figure 14) is much the same as that of instar one, with the following differences: the three thoracic segments have one less seta on the leg base; the meso- and metathorax have seta theta present (absent in instar one); on the abdominal segments, seta $m u$ is present (absent in instar one); the pi group consists of two setae on abdominal segments 1 and 7, three setae on segments $2-6$, and one seta on segments 8 and 9 (cf. instar one); seta epsilon (absent in instar one) is vestigial. 
The crochets and the suranal plate are as in instar one.

The only other detailed description of a thyridid larva, is that by Heinrich (1921) for Meskea dyspteraria from Texas, U.S.A. It and Dysodia are similar, although Meskea has one more seta on the mesothorax (Dysodia missing theta); and on abdominal segment 9 (Dysodia missing eta).

\section{Pupation}

Three or four days before pupation, the larva stops eating and contracts somewhat (Figure 4). The body color changes from white to yellow. The pinacula bearing the setae become brown. The integument is clear at this stage, and the peripheral tracheation can be seen clearly.

Larvae in captivity made pupal chambers of leaf and silk. However, a survey of rolled Piper and Pothomorphe leaves in the Laboratory Clearing did not yield any pupae, so it is likely that the larva either abandons its plant to construct a cocoon elsewhere, or it forms a cocoon which becomes detached from the foodplant before pupation.

Pupa

The pupa (Figure 15) is obtect, dark brown, $14 \mathrm{~mm}$ long, and $6 \mathrm{~mm}$ wide. The maxillae extend to the caudal margin of the fore wings, and are $9 \mathrm{~mm}$ long. The prothoracic legs are about half the length of the fore wings; their femora are exposed between the protibia and the maxillae. The mesothoracic legs extend to the caudal margin of the fore wings. The antennae reach to within $2 \mathrm{~mm}$ of the caudal margin of the fore wings. The mesothoracic spiracle (between pro- and mesothorax) is larger than the abdominal spiracles. The pro-, meso-, and metathorax are $2 \mathrm{~mm}, 3.9 \mathrm{~mm}$, and $0.9 \mathrm{~mm}$ wide respectively. The cremaster bears eight hooked setae.

Heinrich's (1921) illustration of the pupa of Meskea is similar, but the maxillae are only one third the wing length.

\section{Diapause and Eclosion}

Two of the six individuals (nos. 4 and 7) reared to adult had pupal periods of about three weeks (Table 2). The other four (nos. 1, 3, 5, and 6) entered diapause and remained as pupae for eight to ten weeks. The two non-diapause individuals completed their development (egg to adult) in 44 and 49 days, while the four diapause individuals 

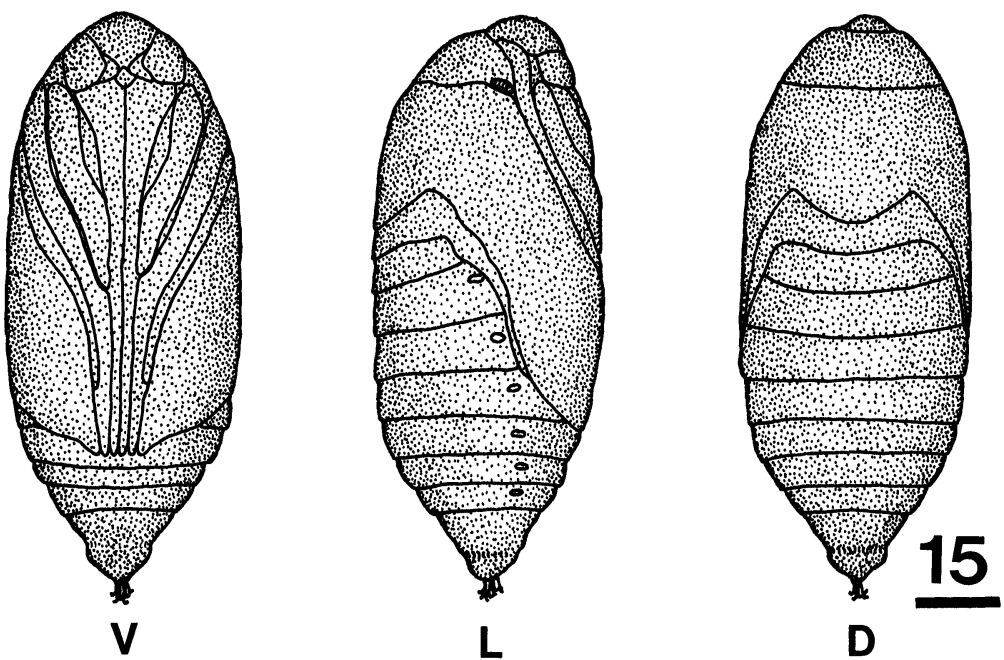

Figure 15. Pupa: ventral (V), lateral (L), and dorsal (D), views. Scale $=2 \mathrm{~mm}$.

completed theirs in $84,88,90$, and 96 days and thus emerged as adults at the same time as the next brood.

All six adults eclosed during late afternoon.

\section{Broods}

Egg batches were first observed in May; additional batches appeared at intervals of about six weeks. Apparently there are several synchronous broods per wet season on BCI.

\section{PARASITES}

A larva (Lot 80-77) collected 22 July 1980 was eaten by the larva of a tachinid fly. The fly larva formed a puparium inside the skin of its host on 27 July, and eclosed from the head end of the host skin on 15 August 1980.

Four eggs were parasitized by wasps (unidentified) less than $1 \mathrm{~mm}$ long.

\section{ACKNOWLEDGEMENTS}

I would like to thank the Smithsonian Tropical Research Institute, Panama, for use of their facilities, Dr. Paul Whalley of the British 
Museum (Natural History) for identification of the moth, and Dr. Robert Olberg for assistance with rearing.

\section{REFERENCES}

Boisduval, M. J. A.

1829. Essai sur une Monographie de Zygénides, suivi du Tableau Méthodique, des Lépidoptéres d'Europe. xxvi +132 pp., 8 pl.

Bose, B. B.

1935. Life-histories of some Indian Thyrididae (Lepidoptera). Indian Journ Agric Sci, 5(6): 737-742.

Clemens, B.

1861. Contributions to American Lepidopterology-No. 6. Proc Acad Nat Sci Philad, 1860: 345-362.

DYAR, H. G.

1913. The American species of Dysodia. Insecutor Inscitiae Menstruus, 1(4): $37-45$.

FORBES, W. T. M.

1942. The Lepidoptera of Barro Colorado Island, Panama. No. 2. Bull Mus Comp Zool 90(2): 265-406, pl. 9-16.

HeINRICH, C.

1921. Some Lepidoptera likely to be confused with the pink bollworm. Journ Agric Res 20(11): 807-836.

Mosher, E.

1916. A classification of the Lepidoptera based on characters of the pupa. Bull Ill State Lab Nat Hist, 12: 15-159, 27 pl.

Peterson, A.

1962. Larvae of Insects: An Introduction to Nearctic Species. Part I. Lepidoptera and Plant Infesting Hymenoptera. 315 pp. Ohio State University Press. Columbus, Ohio.

Whalley, P. E.

1971. The Thyrididae (Lepidoptera) of Africa and its islands: a taxonomic and zoogeographic study. Bull Brit Mus Nat Hist Ent, Supplement 17: 1-198. 

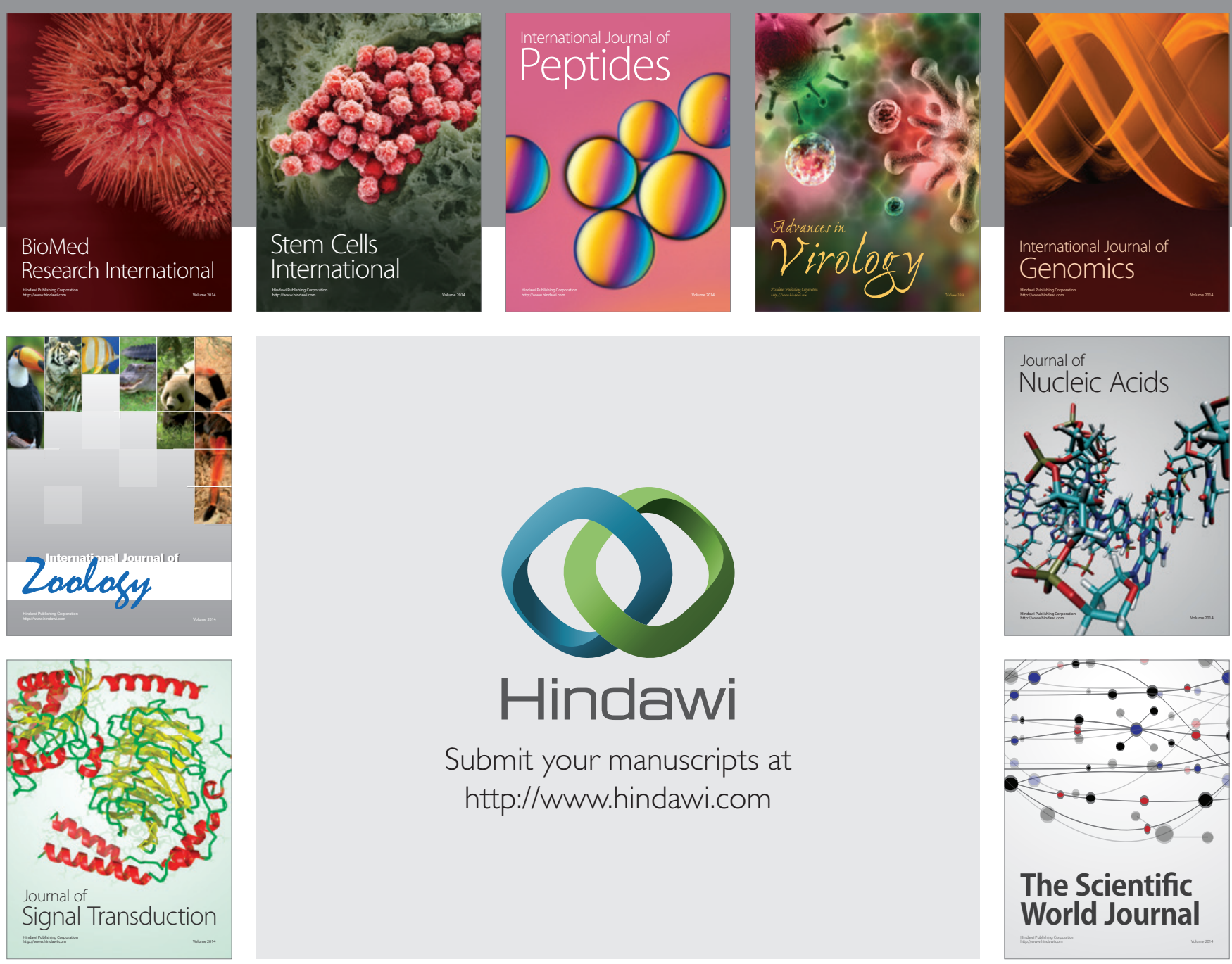

Submit your manuscripts at

http://www.hindawi.com
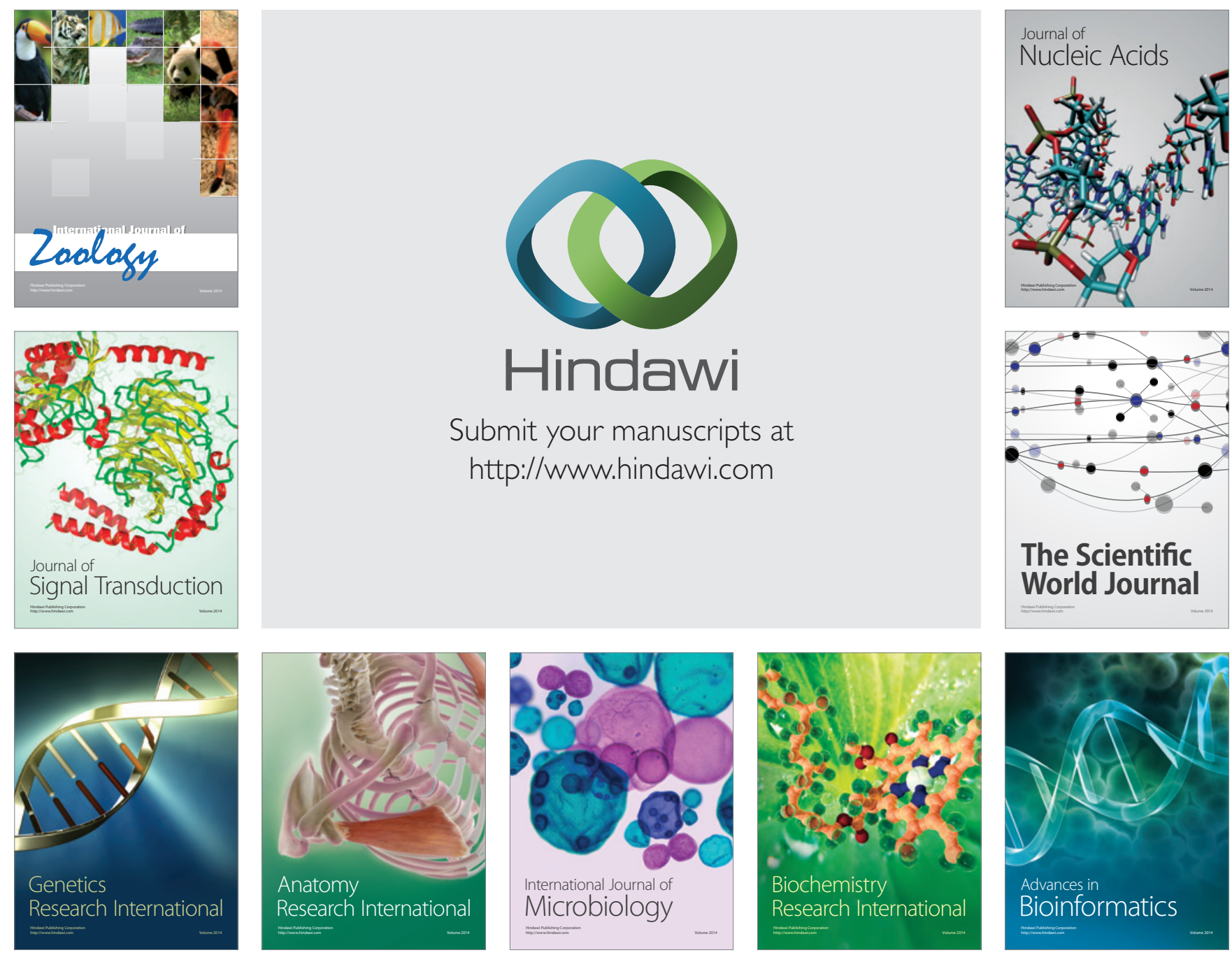

The Scientific World Journal
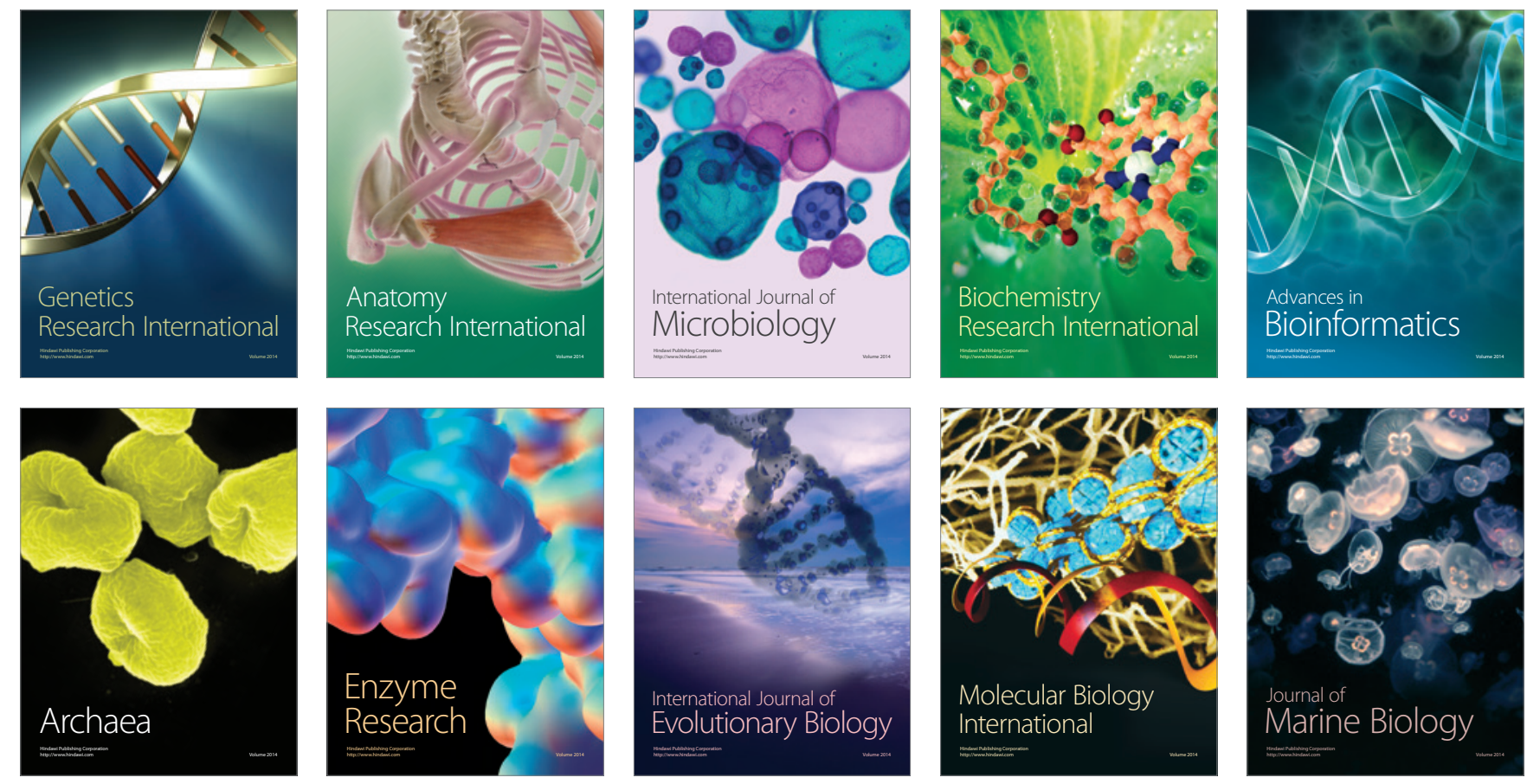